\title{
Measuring the Effects of Relationship Quality and Mutual Trust on Degree of Inter-Firm Technology Transfer in International Joint Venture
}

\author{
Sazali Abdul Wahab \\ National Defence University of Malaysia, Kuala Lumpur, 57000, Malaysia \\ Tel: 60-3-9051-3060_E-mail: saw@upnm.edu.my \\ Raduan Che Rose \\ National Defence University of Malaysia, Kuala Lumpur, 57000, Malaysia \\ E-mail: raduan@upnm.edu.my \\ Suzana Idayu Wati Osman \\ Felda Global Ventures Holdings \\ E-mail: suzana.iwo@gmail.com
}

Received: October 21, 2010 Accepted: November 12, $2010 \quad$ doi:10.5539/ibr.v4n3p116

\begin{abstract}
The success of technology transfer (TT) within international joint ventures (IJVs) in the developing countries has frequently been measured by the degree of technology that is transferred to local partners. As compared to other formal technology transfer agents such as foreign direct investments (FDIs) and licensing, technology transfer through IJVs have been acknowledged by many studies as the most efficient mechanism to internalize the foreign partner's technologies, knowledge and skills which are organizationally embedded. However, the transfer process has always involved a complex relationship between IJV partners which may cause direct impact on degree of technology transfer. The success of inter-firm TT requires a strong existence of a close and intense communications between the technology supplier and recipient. The main objective of this paper is to empirically examine the effects of two critical elements of relationship characteristics: relationship quality and mutual trust on two dimensions of degree of technology transfer: degree of tacit and explicit knowledge. Using the quantitative analytical approach, the theoretical model and hypotheses in this study were tested based on empirical data gathered from 128 joint venture companies registered with the Registrar of Companies of Malaysia (ROC). Data obtained from the survey questionnaires were analyzed using the correlation coefficients and multiple linear regressions. The results revealed that relationship quality, as the critical element of relationship characteristics, has a significant effect on both degrees of tacit and explicit knowledge; where the effect was slightly stronger on degree of explicit knowledge. Similarly, mutual trust between partners has shown consistent strong significant effects on both degrees of tacit and explicit knowledge; where its effect on degree of tacit knowledge was found slightly stronger than degree of explicit knowledge. The study has bridged the literature gaps in such that it offers empirical evidence on the effects of two generic relationship attributes: relationship quality and mutual trust on two dimensions of degree of inter-firm technology transfer: degree of tacit and explicit knowledge in IJVs.
\end{abstract}

Keywords: Inter-Firm Technology Transfer, International Joint Ventures, Relationship Quality, Mutual Trust, Malaysia.

\section{Introduction}

The current issue on inter-firm technology transfer (TT) in the developing countries is revolved around the issue of efficiency and effectiveness of the transfer process by the multinationals (MNCs) (Pak and Park, 2004; Yin and Bao, 2006). Therefore, organizations in the developing countries are attempting to collaborate, learn and internalize their foreign partner's technological knowledge by forming strategic alliances and IJVs with foreign multinational corporations (MNCs) as an efficient mean to enhance their global competitiveness, technological capabilities, and potential for local innovation. Nevertheless, the inter-firm technology transfers (TT) in IJVs have often involved tradeoffs between the technology suppliers' willingness to transfer their considerable amount of technologies; which include tacit and explicit knowledge, degree of protection of the proprietary technology (knowledge and 
competencies) as the source of the supplier's competitive advantage (Inkpen, 2000), degree of transparency (Hamel, 1991), and motivation to transfer (Szulanski, 1996).

Previous studies on intra-firm knowledge transfer have confirmed the significant influence of technology actors and facilitators (barriers) such as the characteristics of knowledge transferred, source, recipient and contextual/relational on knowledge transfer process (Szulanski, 1996, 2000, 2003; Gupta and Govindarajan, 2000; Minbaeva, 2007). Thus, in the context of inter-firm TT where technology transfer processes involve more complex relationship, the impending issue now is on the extent of effects of relationship characteristics (RCHAR) on degree or level of technology transfer (TTDEG). Relationship characteristic, as one of the important TT characteristics, have increasingly become dominant factors in determining the success or failure of inter-firm technology transfer within IJVs (Pak and Park, 2004; Minbaeva, 2007). Studies from the KBV perspective have acknowledged that MNCs tend to become more protective of their advance technology, knowledge and competencies in products, processes and management because these strategic valuable resources and competencies are their main sources of sustainable competitive advantage (Porter, 1985; Barney, 1991; Peteraf, 1993; Wernerfelt, 1984; Pralahad and Hamel). The OL perspective studies have also argued that technology and knowledge are protected by the supplier when the recipients are opportunistic in the collaborative relationship (Inkpen, 1998a; Inkpen and Dinur, 1998; Child and Faulkner, 1998). Motivated by limited empirical studies on inter-firm technology transfer and in response to literature gaps, this study empirically examine the effects of two critical elements of relationship characteristics: relationship quality (RELQLTY) and mutual trust (MT) on two dimensions of degree of technology transfer: degree of tacit (TCTDEG) and explicit (EXPDEG) knowledge from the local (recipient) firms' perspective based on the underlying KBV and OL perspectives.

A large stream of literatures has identified the relationship characteristic (RCHAR); which include JV's characteristics, as organizational distance (Simonin, 1999a, 1999b), cultural distance (Lyles and Salk, 1996; Mowery et al., 1996; Choi and Lee, 1997; Inkpen, 1998a, 1998b, Liu and Vince, 1999), organizational context (Kogut and Zander, 1993; Zander and Kogut, 1995), knowledge connection (Inkpen, 2000), organizational structure (Inkpen, 1997), ownership type (Kogut, 1988; Mowery et al., 1996), ownership equity (Pak and Park, 2004), relationship openness (Hamel, 1991; Inkpen, 2000), partners attachment (Inkpen and Beamish, 1997), inter-partner trust (Baughn et al., 1997; Morrison and Mezentseff, 1997; Love and Gunasekaran, 1999, Inkpen, 2000), empathy (Buckley et al., 2002), relationship quality and strength (Szulanski, 1996; Lin, 2005), relational openness (Wathne et al., 1996), relational capital (Kale et al., 2000), informal relationship (Clarke et al., 1998), articulated goals and management commitment (Choi and Lee, 1997; Morrison and Mezentseff, 1997), and legal, political and technical differences (Marcotte and Niosi, 2000).

\section{Theory and Hypotheses}

\subsection{Relationship Quality and Degree of Technology Transfer}

In order to facilitate the intra and inter-firm TT, both technology supplier and recipient are expected to establish a close relationship between them. For firms which have differences in terms of the organizational structures, cultural backgrounds, experiences, capabilities, learning intent and technological resources, transferring technology is rather a challenging process (Argote, 1999; Hamel, 1991). As knowledge is a firm-specific, embedded in firm organizational context, personal in nature and idiosyncrasy (Nonaka, 1994; Kogut and Zander, 1992, 1993), acquiring and transferring technology require frequent and effective interactions between the supplier and recipient (Bresman et al., 1999). A review of literature on both intra and inter-firm knowledge transfer (KT) reveals that RELQLTY has been operationalized from many dimensions such as 1) ease of communication and intimacy of relationship between the source and recipient unit (Szulanski, 1996), 2) existence and richness of transmission channels (Gupta and Govindarajan, 2000), 3) degree of interaction frequency between the sender and receiver (Lin, 2005), 4) openness of communication, spontaneous, and open exchange of information and ideas between the interacting parties (Gupta, 1987), 5) numerous individual exchanges (Szulanski, 1996; Nonaka, 1994), 6) frequency, adequacy, amiability and constructiveness in interaction (Lin, 2005), 7) productive interaction/relationship (Wang et al., 2004; Inkpen, 1998a), 8) extensive and effective inter-personal communication (Bresman et al., 1999), 9) meaningful and timely information (Anderson and Narus, 1990), 10) close and intense interaction between individual members of the alliance partners (von Hippel, 1988; Marsden, 1990), 11) personal attachment between partners (Luo, 2001), and 12) extensive communication between JV's partners (Inkpen, 2000).

The importance of numerous individual exchanges in transferring tacit knowledge within organization is achievable through "ease of communication and intimacy of relationship" between the source and recipient units thus a problematic relationship between the source and recipient will lead to hardships in transferring knowledge (Szulanski, 1996). Gupta and Govindarajan (2000) argue that the existence and richness of transmission channels as an important determinant of knowledge flows within MNCs. Informality, openness and communication density are closely related to relationship quality as they 1) indicate higher degree of involvement and interaction frequency 
between the sender and receiver, 2) increase the openness of communication, spontaneous and open exchange of information and ideas between the interacting parties, and 3) create potential for numerous individual exchanges (Szulanski, 1996; Nonaka, 1994; Lin, 2005; Gupta, 1987). From the inter-firm KT context, Lin (2005) categorizes quality interaction in terms of its frequency, adequacy, amiability and constructiveness.

Strategic alliance literature has explicitly highlighted that RELQLTY or quality of interaction between alliance partners promotes greater opportunity to learn, share and access to the alliance partners' strategic knowledge and competencies. RELQLTY creates higher relationship openness; which directly affects the willingness and ability of alliance partners to share information and communicate openly (Inkpen, 1998a, 2000). The inter-partner RELQLTY is also reflected on the formal and informal sharing of meaningful and timely information (Anderson and Narus, 1990). Relationship openness between collaborative partners is acknowledged as 1) a key factor in determining the amount of information shared, degree of accessibility of alliance knowledge and the success of knowledge acquisition by alliance partner (Inkpen, 2000), and 2) an essential element in the organizational learning process; which suggest that more resources are likely to be invested in learning by the parent firms that regard their alliance relationship as open (Hamel, 1991). Thus, a close and intense interaction between alliances partners act as an effective mechanism to acquire, transfer or learn tacit and explicit knowledge across the organizational interface (von Hippel, 1988; Marsden, 1990; Kale et al., 2000). Empirical studies examining the relationship between RELQLTY and knowledge transfer are found to be very limited as most of them are theoretical although the previous researchers have highlighted its importance effects on knowledge acquisition (Yin and Bao, 2006). Many intra-firm studies have offered evidence that RELQLTY provides a positive impact on KT (Szulanski, 1996; Minbaeva, 2007; Hansen, 1999, 2002; Gupta and Govindarajan, 2000). Surprisingly, in the context of inter-firm KT although RELQLTY has been extensively debated by the literature, nevertheless, the empirical studies are still very limited. In the context of inter-firm KT, RELQLTY has a significant positive impact on knowledge acquisition (Lin, 2005), and effective interpersonal communication between supplier and recipient through visits and meetings has significantly facilitated cross border KT (Bresman et al., 1999). As opposed to quality interaction, the JV literature has established that conflicts in general may lead to instability and poor JVs performance (Killing, 1983; Lane and Beamish, 1990) thus minimizing the flow of information and knowledge (Fiol and Lyles, 1985; Lane and Beamish, 1990; Parkhe, 1993).

H1: Relationship quality between IJV partners is positively related to a higher degree of tacit and explicit knowledge in inter-firm technology transfer.

\subsection{Mutual Trust and Degree of Technology Transfer}

Inter-partner mutual trust (MT) is critical in the collaborative relationship as MT 1) develops a sense of openness and shared understanding between partners (Dyer and Nobeoka, 2000), 2) facilitates greater accessibility to the alliance knowledge and knowledge acquisition (Inkpen, 1998a, 2000), 3) creates opportunities for a mutual inter-organizational learning; when partners become more open and committed in sharing their knowledge and competencies (Inkpen and Dinur, 1998; Inkpen and Beamish, 1997), 4) reduces the partners' protectiveness of their knowledge and promotes free exchange of information between partners (Inkpen, 2000), 5) creates higher propensity of inter-partner learning as knowledge is more accessible (Hamel, 1991; Doz, and Hamel, 1998; Inkpen, 2000), 6) reduces the fear of opportunistic behaviors of the learning partner and promotes greater transparency between the exchange processes (Gulati, 1995), 7) promotes knowledge acquisition (Glaister et al., 2003; Inkpen and Tsang, 2005), and 8) fosters norms of reciprocity (Nahapiet and Ghoshal, 1998).

High degree of MT in a collaborative relationship strongly indicates that the partners 1) accept each other as an ally not as competitor (Powell et al., 1996), 2) signify their commitment by not taking advantage on the other partner's weaknesses or vulnerabilities (Steensma and Lyles, 2000), and 3) are more willing to provide information to knowledge learning and sharing; particularly when partners are less suspicious of the other partner's opportunistic behaviors (Child and Faulkner, 1998). Trust develops potential access to the alliance's valuable resources and willingness to solve problems through mutual problem-solving (Uzzi, 1997). A collaborative alliance with low degree of trust will reduce the partner openness (transparency) in knowledge sharing and learning thus limiting the information's accuracy, comprehensiveness and timeliness (Zand, 1972; Kale et al., 2000) as the partners are reluctant to face the risk associated with sharing more valuable information (Hedlund, 1994). A lack of inter-partner trust may generate inter-firm conflicts, increase opportunistic behaviors; which eventually erode mutual understanding (Tsang et al., 2004). The inter-partner trust also acts as an ongoing social control mechanism and risk reduction device as it determines the extent of knowledge exchange in IJVs and the efficiency with which it is exchanged (Lane et al., 2001). Trust is also crucial in alliances and IJVs as no contracts/agreements can cover all the variations and conditions that can occur (Dhanaraj et al., 2004).

Trust between partners may help to develop mutual partner understanding, increase knowledge accessibility (Inkpen, 1998a) and contribute to a freer and greater exchange of information and know-how between alliances partners 
(Kale et al., 2000). Past studies on MT are mainly theoretical (Nielsen, 2007). Nevertheless, few empirical studies have suggested that MT between alliance partners as an important determinant in the alliance performance in terms of 1) reducing search cost, increasing efficiency, enhancing benefits and alliance's performance (Gulati, 1995), 2) increasing alliance's cooperation, improving flexibility, reducing coordinating activities cost and increasing KT and learning (Smith et al., 1995) and, 3) reducing negotiating costs in alliances and enhancing alliance performance (Zaheer et al., 1998). Few strategic alliance studies on IJVs have also offered empirical evidence. In general, MT has a significant positive relationships with 1) the alliance performance (Nielsen, 2007), 2) learning in strategic alliance (Kale et al., 2000), 3) international cooperative ventures (ICVs) performance (Luo, 2001), and 4) tacit knowledge transfer in IJVs (Dhanaraj et al., 2004). On the other hand, Pak and Park's (2004) findings suggest that inter-firm conflicts erode MT when the transferring partners tend to be more protective of their knowledge and unwilling to share knowledge due to suspicion of opportunistic behaviors of the recipient partners.

H2: Mutual Trust between IJV partners is positively related to a higher degree of tacit and explicit knowledge in inter-firm technology transfer.

\section{Methods}

\subsection{Sample}

The sample frame was taken from the IJV companies registered with the Registrar of Companies (ROC). The IJV companies that participate in this study are selected based on four main criteria: 1) the IJV companies are from industries where technology is the basis for competitive advantage, 2) the IJV companies are formed more than 2 years and had actively engaged in technology transfer through JVs, 3) the IJV companies whose foreign partners are from the U.S, Europe, Japan, and other Asian countries such as Korea, Taiwan and Singapore (Yin and Bao, 2006), and 4) the foreign firms (parent) have at least 20 percent (\%) equity in the JVs (Inkpen, 1995a; Makino and Beamish, 1998). As at $1^{\text {st }}$ January 2008, the number of IJVs operating in Malaysia was 1038. Out of this, 850 IJVs were considered as active IJVs and $103 \mathrm{IJVs}$ were either dormant or had ceased operation. Since the focus of this study is on inter-firm TT from foreign MNCs to local companies, $85 \mathrm{IJVs}$ were further eliminated from the population frame because only IJVs that have operated more than 2 years and have at least twenty percent (20\%) of foreign equity are eligible to participate in the survey. Therefore, based on the list provided by ROC, which is considered as the most official and original source of information on foreign investment in Malaysia, it was decided that all IJVs (850) be included in the survey. Data collection was conducted in the period from July 2008 to December 2008 using a self-administered questionnaire. The questionnaires were mailed to 850 active JV companies as listed with ROC using a cover letter. After one month from the posting date the response was found not encouraging. By mid July 2008 there were only 70 responses received from the respondents. Thus, in order to increase the response rate the researcher followed-up through numerous phone calls, e-mails, reminders via letters and personal visits to seek the respondents' cooperation in the survey. After intensive efforts were made, by mid November 2008 a total of 145 responses $(17.05 \%)$ were received. Based on literature review, the response rates for mailed questionnaires are usually not encouraging and low (Newman, 2003; Sakaran, 2003). In the Malaysian context, however, a response rate of $15 \%$ to $25 \%$ is still being considered appropriate and acceptable (Mohammed, 1998; Rozhan, Rohayu and Rasidah, 2001). From 145 responses only 128 questionnaires were usable and 17 questionnaires were returned blank, returned incomplete, or replied but unable to participate in the study.

The selection of the sample is based on census sampling technique where the data is gathered from all the identified members/elements in the final population sample frame of 850 active JVs companies registered with ROC. In this study, the census sampling is employed as it provides an advantage by 1) eliminating the possibility that by chance a randomly selected sample may not be adequate representative of the sample, 2) gathering detailed information on the sub-groups in the population, and 3) reducing sampling variability attributed to statistic as it is calculated using data from all elements/JV companies in the population (Black, 2001). Thus, census sampling method reduces the risk of omitting or missing out any elements/JVs companies in the population as compared to random sampling method; where the possibility to omit or miss out the elements/JVs companies is higher (Sekaran, 2003).

\subsection{Instrument and measurement}

The main research instrument in this study is the questionnaire. Building on the previous KT and TT studies, the questionnaire adopts a multi-item scales which have been modified accordingly to suit the context of the study: inter-firm TT. Except for degree of technology transfer (TTDEG), all the variables are measured using ten-point Likert Scale $(1=$ strongly disagree to $10=$ strongly agree). For TTDEG, this variable is measured using ten-point Likert Scale $(1=$ very low transfer to $10=$ substantial transfer $)$. The ten-point Likert Scale was selected because 1) the wider distribution of scores around the mean provides more discriminating power, 2) it is easy to establish covariance between two variables with greater dispersion around their means, 3) it has been well established in academic and industry research, and 4) from a model development perspective, a ten-point scale is more preferred (Allen and Rao, 2000). 
The content validity of the scales used in this study is established by their origin from previous literatures. The scales are deemed to be validated since this study has fully adopted with modification the established scales in the literature which have been developed by well known researchers (experts) in the study's field (Sekaran, 2003). To ensure the validity of the scales used, the variables in this study are measured by multi-item scales adopted from well established studies on intra and inter-firm technology and knowledge transfer. Using the SPSS, the internal consistency and reliability of the scales used are analyzed. In this study the Cronbach alpha ranges from 0.926 to 0.9720 . Thus, the results of reliability tests indicate that the scales used are consistent and the scales' reliability is well above the acceptable rule of thumb of .70 (Hair et al., 1998). This indicates that the scales used in this study, which have been adopted from previous established studies, are highly reliable.

The percentage of number of samples collected from the population in this study is relatively low (17.05\%), although this is acceptable (Mohammed, 1998; Rozhan, Rohayu and Rasidah, 2001). From 850 questionnaires distributed to JVs companies only 145 respondents returned the questionnaire, and out of this 128 samples are considered completed and usable. Therefore, in order to eliminate and mitigate the non response bias in the study's findings, this study follows Miller and Smith's (1983) suggestion that is 'to compare the difference between early respondents and late respondents to justify generalizing from the respondents to the sample' (pg. 48). Using information on MNCs' size, age of joint venture, MNCs' country of origin and MNCs' types of industry, a t- test analysis was conducted to test the differences, with the late respondents assumed to be similar to non-respondents (Oppenheim, 1966). Upon conducting the t-test, the results reveal that there is no difference in the responses on local firms' performance (LFP) and degree of technology transfer (TTDEG) provided by the first 40 early respondents and the 40 late respondents. From the t-test results it can be reasonably concluded that non-response bias was not detected in this study. The significance 2-tailed results indicate that there is no significant difference between the early respondents and late respondent suggesting that non-response bias does not exist and all the $p$ values are above 0.5 levels $(\mathrm{p}>0.5)$.

\subsection{Dependent Variable - Degree of Technology Transfer (TTDEG)}

Following Lyles and Salk (1996), Lane et al. (2001), Gupta and Govindarajan (2000), Dhanaraj et al. (2004), Pak and Park (2004), Yin and Boa (2006) and Minbaeva (2007), this study adopts "a multi-dimensional operationalization approach" in measuring this construct. This study operationalizes TTDEG as the transfer of technological knowledge in terms of two dimensions: 1) tacit knowledge (TCTDEG) in terms of new product/service development, managerial systems and practice, process designs and new marketing expertise, and 2) explicit knowledge (EXPDEG) in terms of manufacturing/service techniques/skills, promotion techniques/skills, distribution know-how, and purchasing know-how. The respondents were asked to evaluate TTDEG from MNCs to local firms in terms of tacit and explicit dimensions of technological knowledge. The Cronbach Alphas for TCTDEG and EXPDEG were 0.96 and 0.97 respectively. The results of Cronbach Alpha were quite similar to that of Hau and Evangelista (2007) and Yin and Bao (2006).

\subsection{Independent Variables}

3.4.1 Relationship Quality (RELQLTY)

This study operationalizes RELQLTY in terms of relationship informality, openness and communication density; which increases the exchange of information, technology and knowledge between partners (Gupta, 1987; Gupta and Govindarajan, 2000; Lin, 2005). To capture this construct, this study employs a four (4) items scale developed by Lin (2005) in which the items are designed to capture 1) the local JV partner efforts in maintaining frequent interaction with the foreign JV partner, 2) the adequacy of the interaction, 3) the local JV partner effort in maintaining an amiable climate for the interaction, and 4) the local JV partner's effort in ensuring that interaction is a constructive mode. As RELQLTY (informality, openness and communication density) is explained by the relationship strength, this study adopts a seven (7) items scale adopted from Cavusgil et al. (2003), Chua (2002), and Fryxell et al. (2002). RELQLTY is measured in terms of 1) the desire to maintain a good social relationship by the foreign and local JV partners, 2) the foreign and local JV partners can freely talk to each other about difficulties (in general) they encounter with JV and they know that their concern will be addressed, 3) the foreign and local JV partners are confident in each other's capabilities, 4) the foreign and local JV partners are free to share their ideas, feelings and hope with each other, 5) the foreign and local JV partners are supportive of each other and they respond constructively and caringly to their partner's concern about the JV, 6) the foreign and local JV partners share a sense of togetherness, and 7) the foreign and local JV partners share organizational myths and stories with each other. The Cronbach Alpha for RELQLTY was slightly higher (0.96) than that of (Lin, 2005).

3.4.2 Mutual Trust (MT)

This study employs a six (6) items scale developed by Dhanaraj et al. (2004) and five (5) item scales from Kale et al. (2000) to measure MT between JV partners which include statements whether 1) the JV partners can understand each other well and quickly, 2) the JV partners have the feeling of being mislead, 3) the JV partners make damaging 
demands, 4) the stronger JV partner pursues its interest at all costs, 5) the informal agreement are perceived as significant as formal agreement, and 6) the JV partners take advantage on the weakness of the other party (Dhanaraj et al., 2004). In addition, five (5) more items are adopted from Kale et al. (2000) with respect to statements whether the $\mathrm{JV}$ is characterized by close interaction, mutual respect, mutual trust, personal friendship, and reciprocity between the JV partners at multiple levels. The Cronbach Alpha was lower slightly lower (0.88) than Dhanaraj et al. (2004).

\section{Results}

Table 1 shows the descriptive data of all the variables (Mean values, Standard Deviations, Correlations). The results of regression analysis are presented in Table 2. From Table 1, there are clearly some associations between independent variables. For all the variables, it was found that there was no multicollinearity problem; where the $\mathrm{T}$ values were ranged between $0.481-0.491$ and the VIF values were between 2.077 - 2.177 (Tabachnick and Fidell, 1996). Both relationship quality (RELQLTY) and mutual trust (MT) were strongly correlated with degree of tacit knowledge (TCTDEG) $(p<0.01)$. It is also noted that RELQLTY and MT had positive signs indicating consistency with the theoretical arguments in the literature. The correlation results also indicated that both RELQLTY and MT had recorded strong correlations with EXPDEG $(p<0.01)$.

Using multiple regression analysis, the effects of RELQLTY and MT on two dimensions of degree of technology transfer (TCTDEG and EXPDEG) were estimated. As shown in Table 2, relationship quality as a critical component of relationship characteristics had significant effect on both degrees of tacit and explicit knowledge in inter-firm TT. The regression results indicated that RELQLTY in Model 2 had a stronger positive significant effect on degree of explicit knowledge $(p<0.05$, Beta value $=0.406)$ as compared to its effect on degree of tacit knowledge in Model 1 $(p<0.05$, Beta value $=0.214)$. This was also evident by the results of the adjusted $R$-squared in Model 1 and Model 2 ( 0.254 and 0.342 respectively) and the $F$ statistics ( 8.028 and 8.804 respectively). On the corresponding $p$ values, both results were statistically significance $(p=0.001)$. From the regression results $H 1$ is supported thus indicating that the greater degree of RELQLTY, which is directly reflected on close, intimate, and informal relationship between IJV partners, contributes to a higher degree of both tacit and explicit knowledge in inter-firm TT. Interestingly, the effect of RELQLTY on degree of explicit knowledge is stronger than its effect on tacit knowledge. The finding suggests that even if frequent and effective interactions, close relationship, and intimacy of relationship do exist between IJV partners, however, transferring explicit knowledge is equally challenging simply because although explicit knowledge has been explicitly standardized in blueprints, manuals, procedures and instructions by the transferring partner, quite often, it still consists of a highly tacit, complex and specific knowledge; which is difficult to be articulated and understood without the existence of 'teacher-student' relationship.

Consistent with the study's prediction, mutual trust which has strong theoretical foundation showed a similar strong significant effects on both degrees of tacit and explicit knowledge ( $p<0.01$ and $p<0.05$ respectively). As compared to the effect of MT on EXPDEG $(p<0.05)$ in Model 2, MT recorded slightly stronger and better effect on TCTDEG in Model $1(p<0.01)$ indicating a higher degree of tacit knowledge will likely be transferred to recipient partner as compared to explicit knowledge. This suggests that tacit knowledge in IJVs is more accessible by the recipient partner when IJV partners trust each other where no suspicious feelings exist between them. The results further suggest that when the learning partner adopts the collaborative learning intent, the transferring partner will become less protective of their technologies and is more likely to be transparent in sharing tacit knowledge than explicit knowledge. Thus, based on the two regression results for Model 1 and Model 2 above, $H 2$ is supported.

\section{Discussion and Conclusion}

Building on the underlying integrated KBV and OL perspectives, this study has bridged the literature gaps by providing empirical evidence on the effects of two critical elements of relationship characteristics: relationship quality (RELQLTY) and mutual trust (MT) on two distinct dimensions of degree of inter-firm technology transfer: degree of tacit (TCTDEG) and explicit (EXPDEG) knowledge in IJVs using the Malaysian sample. The results are consistent with recent propositions made by the literature; where knowledge attributes are not the only important determinant of knowledge transfer (Minbaeva, 2007; Szulanski and Cappetta, 2003). The presence of strong impact of RELQLTY on both degrees of technology transfer (TCTDEG and EXPDEG) suggests that the greater the quality of relationship the higher the degree of technology transfer within the JVs. The results further suggest that the quality of relationship in JVs in terms of frequent and effective interactions between partners, openness, spontaneous, and adequacy of communication could create potentials for numerous individual exchanges between the JV partners; particularly when the transfers involve a highly specific technology and tacit knowledge (Szulanski, 1996; Lin, 2005; Inkpen, 2000). More opportunities for sharing, learning, and transferring technology will exist if both partners have a higher quality of interactions (Inkpen, 1998). In the collaborative and constructive interactions, RELQLTY is viewed as an effective mechanism to facilitate inter-firm technology transfer as both partners are 
motivated to invest more resources in the JVs and committed to fulfill their commitments. The result also supports and confirms recent empirical findings by Lin (2005); where quality interaction was found to have a significant effect on knowledge acquisition. In line with the current development in the literature, the population data also suggests that 1) RELQLTY has become a major determinant of technology transfer in facilitating a higher degree of technology transfer, and 2) conflicts between JV partners are likely to lead to JV's instability thus minimizing the flows of information.

On the significant effect of mutual trust (MT) on both degrees of technology transfer, the results were expected given that many theoretical studies have consistently highlighted the importance of MT between JV partners (Gulati, 1995; Kale et al., 2000; Powell, 1996). The strong significant positive effects of MT on TCTDEG and EXPDEG suggests that the greater the mutual trust between JV partners the higher the degree of inter-firm technology transfer to local partners. Obviously, this is because MT reduces the existence of suspicious feelings between partners in JVs thus creating opportunities for close interactions, increasing confidence that both partners would not take advantage on each other, and promoting transparency (Kale et al., 2000). In the collaborative ventures such as strategic alliances and JVs, a low degree of trust discourages openness/transparency between partners resulting in a limited accuracy and comprehensiveness of information and technology (Zand, 1972; Kale et al., 2000).

One of the major limitations encountered by this study was the resource constraints; where this study has mainly relied on responses obtained from the top management level of the JVs. Thus, the scope of respondents could have been extended to include the response from the middle and lower management levels in the JVs. Secondly, consistent with the literature, the subjectivity of nature of relationship is difficult to capture. Thus, the nature of relationship between IJV partners could have tremendously affected the results if the respondents perceived that the IJVs were competitive in nature rather than collaborative. Thirdly, due to lack of awareness on academic research the response rate in terms of the number of usable questionnaires, though sufficient, was not encouraging. This has become a major challenge to many researchers who conduct organization studies in Malaysia. Finally, due to time constraints, the types of technology under investigation in this study were limited to tacit and explicit knowledge.

This empirical study is a response to the need for statistical evidence that has typically been lacking in inter-firm TT literature. Since this study focuses on degree of inter-firm TT, future studies could be conducted to further examine the effects of relationship characteristics on level of innovation, competitiveness, productivity, and technological capabilities of local firms. The above relationship could also be extended to cover other formal inter-firm TT agents such as FDIs and licensing. Secondly, it is worthwhile to extend the tacit and explicit dimensions of technology to cover other dimensions of supply chain activities. Future studies may focus on the relationships and effects of relationship characteristics on other dimensions of tacit and explicit technology/knowledge of supply chains such as production, marketing, management, and distribution. Thirdly, since the IJV literature has highlighted the high instability rate of IJVs in developing countries, future studies could be directed to empirically examine the relationships between degree of inter-firm TT and conflicts, learning outcomes, asymmetric bargaining power, stability of JV, and equity ownership. Finally, given the linear relationship between relationship characteristics and degree of inter-firm technology transfer, future studies could further investigate the effects of few established moderating variables such as organizational culture, collaborative know-how, prior JV experience, and learning capacity on the relationship.

\section{References}

Allen, D. R. \& Rao, T. R. (2000). Analysis of Customer Satisfaction Data. United States of America: America Society for Quality

Anderson, J.C. \& Narus, J.A (1990). A Model of Distributor Firm and Manufacturer Firm Working Partnerships, Journal of Marketing, 54, p. 42-58.

Argote, L. (1999). Organizational Learning: Creating, Retaining, and Transferring Knowledge. Boston: Kluwer Academic.

Barney, J.B. (1991). Firm Resources and Sustained Competitive Advantage. Journal of Management, 17,p. 151-166.

Baughn, C. C., Denekamp, J. G, Stevens, J.H. \& Osborn, R.N. (1997). Protecting Intellectual Capital in International Alliances, Journal of World Business, 32(2), p. $103-17$.

Black, K. (2001). Business Statistics: Contemporary Decision Making, Ohio: South-Western.

Bresman, H., Birkinshaw, J. \& Nobel, R. (1999). Knowledge Transfer in International Acquisitions. Journal of International Business Studies, 30(3), p. 439-62.

Buckley, P.J., Glaister, K.W. \& Husan, R. (2002). International Joint Ventures: Partnering Skills and Cross-Cultural Issues, Long Range Planning, 35(2), p. 113-134. 
Cavusgil, S.T., Calantone, R.J. \& Zhao, Y. (2003). Tacit Knowledge Transfer and Firm Innovation Capability. Journal of Business Industrial Marketing, 18(1), p. 6-21.

Child, J. \& Faulkner, D. (1998). Strategies of Cooperation: Managing Alliances Networks and Joint Ventures. Oxford University, New York.

Choi, C.J. \& Lee, S.H. (1997). A Knowledge-Based View of Cooperative Interorganizational Relationships, In: Beamish P, Killings J, (Eds.). Cooperative Strategies, European Perspectives. San Francisco, CA: New Lexington Press; p. 33-58.

Chua, N. (2002). The Influence of Social Interaction on Knowledge Creation. Journal of Intellectual Capital, 3 (4), p. 375-392.

Clarke, C.M., Robinson, T.M. \& Bailey, J. (1998). Skills and Competence Transfer in European Retail Alliances: A Comparison between Alliances and Joint Ventures. European Business Review, 98 (6), p. 300 -310.

Cumming, J.L. \& Teng, B.S. (2003). Transferring R\&D Knowledge: The Keys Factors Affecting Knowledge Transfer Success. Journal of Engineering and Technology Management, 20, p. 39-68

Davenport, T.H. \& L. Prusak, L. (2000). Working Knowledge: How Organizations Manage What They Know. Harvard Business School Press, Boston, MA.

Dhanaraj, C., Lyles, M.A., Steensma, H.K. \& Tihanyi, L. (2004). Managing Tacit and Explicit Knowledge Transfer in IJVs: the Role of Relational Embeddedness and the Impact on Performance, Journal of International Business Studies, 35(5), p. 428-42.

Doz, Y. L. \& Hamel, G. (1998). Alliance Advantage. Boston, MA: Harvard Business School Press.

Dyer, J.H. \& Nobeoka, K. (2000). Creating and Managing a High-Performance Knowledge-Sharing Network: The Toyota Case, Strategic Management Journal, 21(3), p. 345-367.

Dyer, J. \& Singh, H. (1998). The Relational View: Cooperative Strategy and Sources of Interorganizational Competitive Advantage. Academy of Management Review, 23(4), p. 660-679.

Fiol, C.M. \& Lyles, M.A. (1985). Organizational Learning. Academy of Management Journal, 10, p. 803-813.

Fryxell, Gerald, E., Robert, D.S. \& Maria, V. (2002). After the Ink Dries: The Interaction of Trust and Control in US-Based International Joint Ventures. Journal of Management Studies, 39, p. 865-887.

Glaister, K.W., Husan, R. \& Buckley, P.J. (2003). Learning to Manage International Joint Venture. International Business Review, 12(1), pp. 83-108.

Gulati, R., (1995). Does Familiarity Breed Trust? The Implications of Repeated Ties for Contractual Choice in Alliances. Academy of Management Journal 38(1), p. 85-112.

Gupta, A. K. (1987). SBU Strategies, Corporate-SBU Relations, and SBU Effectiveness in Strategy Implementation. Academy of Management Journal, 30, p. 477-500.

Gupta, A. K. \& Govindarajan, V. (2000). Knowledge Flows within Multinational Corporations, Strategic Management Journal, 21(4), p. 473-96.

Hair, J. F., Andersen, R. E., Tatham, R. L. \& Black, W. C. (1998). Multivariate Data Analysis with Readings, New York: MacMillan Publishing.

Hamel G. (1991). Competition for Determinant and Interpartner Learning within International Strategic Alliances. Strategic Management Journal, 12, p. 83-103.

Hamel, G., Doz, Y. \& Prahalad, C. K. (1989). Collaborate with Your Competitors and Win. Harvard Business Review, 67(1), p. 133-139.

Hansen, M. (2002). Knowledge Networks: Explaining Effective Knowledge Sharing in Multiunit Companies, Organization Science, 13(3), p. 232-248.

Hansen, M. (1999). The Search-Transfer Problem: The Role of Weak Ties in Sharing Knowledge Across Organization Subunits, Administrative Science Quarterly, 44 (1), p. 82-111.

Hau, L. N. \& Evangelista, F. (2007). Acquiring Tacit and Explicit Marketing Knowledge from Foreign Partners in IJVs. Journal of Business Research, 60, pp. 1152-1165.

Huber, G. P. (1991). Organizational Learning: The Contributing Processes and the Literature, Organization Science, 2(1), p. 88-115. 
Inkpen, A.C. (2000). Learning through Joint Ventures: A Framework of Knowledge Acquisition. Journal of Management Studies, 37(7), p. 1019-1043.

Inkpen, A. C. (1998a). Learning and Knowledge Acquisition through International Strategic Alliances, The Academy of Management Executive, 12(4), p. 69-80.

Inkpen, A. C. \& Currall, S.C. (2004). The Coevolution of Trust, Control, and Learning in Joint Ventures, Organization Science, 15(5), p. 586-99.

Inkpen, A.C \& Dinur, A. (1998). Knowledge Management Processes and International Joint Ventures. Organization Science, 9(4), p. 454-468.

Inkpen, A.C. \& Beamish, P.W. (1997). Knowledge Bargaining Power and the Instability of International Joint Ventures. Academy of Management Review, 22(1), p. 177-199

Inkpen, A. C. (1995a). The Management of International Joint Ventures: An Organizational Learning Perspective, London, UK: Routledge Press.

Jordan, J. \& Lowe, J. (2004) Protecting Strategic Alliance: Insight from Collaborative Agreement in the Aerospace: Building Relational Capital. Strategic Management Journal, 21 (3), p.241-59.

Kale P., Singh H. \& Perlmutter H. (2000). Learning and Protection of Proprietary Assets in Strategic Alliances: Building Relational Capital. Strategic Management Journal, 21(3), p. 217-37.

Khanna, T., Gulati, R. \& Nohria, N. (1998).The Dynamics of Learning Alliances: Competition Cooperation, and Relative Scope, Strategic Management Journal, 19(3), p. 193-210.

Killing, J. P. (1983). Strategies for Joint Ventures Success. New York: Praeger.

Kogut, B. (1988). Joint Ventures: Theoretical and Empirical Perspectives, Strategic Management Journal, 9(4), p. 319-32.

Kogut, B. \& Zander, U. (1993). Knowledge of the Firm and the Evolutionary Theory of the Multinational Corporation. Journal of International Business Studies, 24(4), p. 625-646.

Kogut, B. \& Zander, U. (1992). Knowledge of the Firm, Combinative Capabilities, and the Replication of Technology, Organization Science, 3(3), 383-97.

Lane, P. J., Salk, J.E. \& Lyles, M.A. (2001). Absorptive Capacity, Learning, and Performance in International Joint Ventures, Strategic Management Journal, 22(12), p. 1139-61.

Lane, H. W. \& Beamish, P. W. (1990). Cross-Cultural Cooperative Behavior in Joint Ventures in LDCs. Management International Review, 30, pp. 87-102.

Lin, X. (2005). Local Partner Acquisition of Managerial Knowledge in International Joint Ventures: Focusing on Foreign Management Control. Management International Review, 45(2), p. 219-237.

Liu, S. \& Vince, R. (1999). The Cultural Context of Learning in International Joint Ventures. Journal of Management Development, 18 (8), p. 666-675.

Love, P.E.D. \& Gunasekaran, A. (1999). Learning Alliances: A Customer-Supplier Focus for Continuous Improvement in Manufacturing. Industrial and Commercial Training, 31 (3), 88-96.

Luo, Y. (2001). Antecedents and Consequences of Personal Attachment in Cross-Cultural Cooperative Ventures. Administrative Science Quarterly, 46(2), p. 177-201.

Lyles, M. A., Sulaman M, Barden J. Q. \& Kechik ARBA (1999) Factors Affecting International Joint Venture Performance: A Study of Malaysian Joint Ventures. Journal of Asian Business, 15(2), p. 1-19.

Lyles, M. A. \& Salk, J.E. (1996). Knowledge Acquisition from Foreign Parents in International Joint Ventures: An Empirical Examination in the Hungarian. Journal of International Business Studies, 29(2), p. 154-74.

Lyles, M.A., von Krogh, G. \& Aadne, J.H. (2003). Knowledge Acquisition and Knowledge Enablers in International Joint Ventures and their Foreign Parents. Management International Review, 3, Special Issue, p. 111-129.

Makino, S. \& Beamish, P. W. (1998). Performance and Survival of Joint Ventures with Non-Conventional ownership structures. Journal of International Business Studies, 29 (4), p. 797-818.

Marcotte, C. \& Niossi, J. (2000). Technology Transfer to China: The Issues of Knowledge and Learning, Journal of Technology Transfer, 25, p. 43-57.

Marsden, P.V. (1990). Network Data and Management, Annual Review of Sociology, 16, p.435-463. 
Martin, X.Y.F. \& Salomon, R. (2003). Knowledge Transfer Capacity and its Implications for the Theory of the Multinational Corporation. Journal of International Business Studies, 34(4), p. 356-373.

Miller L. E. \& Smith K. L. (1983). Handling Non Response Issues. Journal of Extension, September/October, p. 45-49.

Minbaeva, D. (2007). Knowledge Transfer in Multinationals, Management International Review, 47(4), p. 567-593.

Minbaeva, D. \& Michailova, S. (2004). Knowledge Transfer and Expatriation Practices in MNCs: The Role of Disseminative Capacity, Employee Relations, 26(6), p. 663-679.

Mjoen H. \& Tallman, S. (1997). Control and Performance in International Joint Ventures. Organization Science, 8(3), p. 257-274.

Mohamed, M.Z (1998). Assessing the Competitiveness of the Malaysian Electronic and Electrical Industry: Part 1-Technology Adoption. Malaysian Management Review, 33(10), p. 19-20.

Morrison, M. \& Mezentseff, L. (1997). Learning Alliances - A New Dimension of Strategic Alliances. Management Decision, MCB University Press, 35(5), p. 351-357.

Mowery, D.C., Oxley J.E. \& Silverman B.S. (1996). Strategic Alliances and Interfirm Knowledge Transfer. Strategic Management Journal, 17, p. 77-91.

Nahapiet, J. \& Ghoshal, S. (1998). Social Capital, Intellectual Capital and the Organizational Advantage. Academy of Management Review, 23(2), pp. 242-266.

Newman, L. W. (2003). Social Research Methods: Qualitative and Quantitative Approaches. (5 ${ }^{\text {th }}$ Eds). Allyn and Bacon. Boston. MA.

Nielsen, B.B. (2007). Determining International Strategic Alliance Performance: A Multidimensional Approach. International Business Review, 16, p. 337-361.

Nonaka, I. (1994). A Dynamic Theory of Organizational Knowledge Creation. Organization Science, 5, p. 14-37.

Oppenheim, A. N. (1966). Questionnaire Design and Attitude Measurement, London: Heinemann.

Pak, Y. \& Park, Y. (2004). A Framework of Knowledge Transfer in Cross-Border Joint Ventures: An Empirical Test of the Korean Context, Management International Review, 44(4), p. 435-455.

Parkhe, A. (1993). Partner Nationality and the Structure-performance Relationships in Strategic Alliances, Organization Science, 4(2), p. 301-14.

Petaraf, M.A. (1993). The Cornerstone of Competitive Advantage: A Resourced-Based View. Strategic Management Journal, 14(3), p. 179-192.

Porter, M.E. (1985). Competitive Advantage: Creating and Sustaining Superior Performance. Free Press: New York.

Powell, W.W., Kenneth W. K. \& Laurel S. D. (1996). Interorganizational Collaboration and the Locus of Innovation: Networks of Learning in Biotechnology. Administrative Science Quarterly, 41, p. 116-145.

Pralahad, C.K. \& Hamel, G. (1990). The Core Competence of the Corporation. Harvard Business Review, 68, p. 77-91.

Rozhan, O., Rahayu \& Rashidah. (2001). Great Expectation: CEO's Perception of the Performance Gap of the HRM functions in the Malaysian Manufacturing Sector. Personnel Review, 30 (1), 1\& 2, p. 61-80.

Sekaran, U. (2003). Research Methods for Business, Fourth Edition, John Wiley \& Sons, Inc.

Simonin, B. L. (2004). An Empirical Investigation of the Process of Knowledge Transfer in International Strategic Alliances, Journal of International Business Studies, 35(5), 407-27.

Simonin, B. L. (1999a). Ambiguity and the Process of Knowledge Transfer in Strategic Alliances, Strategic Management Journal, 20(7), p. 595-623.

Simonin, B.L. (1999b). Transfer of Marketing Know-how in International Strategic Alliances: An Empirical Investigation of the Role and Antecedents of Knowledge Ambiguity. Journal of International Business Studies, 30(3) p. 463-90 [Third Quarter].

Smith, K.G., Carroll, S.J. \& Ashford, S.J. (1995). Intra and Inter OrganizationaC: Towards a Research Agenda. Academy of Management Journal, 38(1), p.7-23.

Steensma, H. K. \& Lyles, M.A. (2000). Explaining IJV Survival in a Transitional Economy through Social Exchange and Knowledge-based perspectives, Strategic Management Journal, 21(8), p. 831-51. 
Subramaniam, M. \& Venkatraman, N. (2001). Determinants of Transnational New Product Development Capability: Testing the Influence of Transferring and Deploying Tacit Overseas Knowledge', Strategic Management Journal, 22(4): 359-378.

Szulanski, G. (2000). Appropriability and the Challenge of Scope: Bank One Routinizes Replication, in Dosi, G. Nelson, R. Winter, S. (Eds.), the Nature and Dynamics of Organizational Capabilities, New York: Oxford University Press.

Szulanski, G. (1996). Exploring Internal Stickiness: Impediments to the Transfer of Best Practice within the Firm, Strategic Management Journal, 17 (Winter Special Issue), p. 27-43.

Szulanski, G. \& Cappetta, R. (2003). Conceptualizing, Measuring and Predicting Difficulties in the Transfer of knowledge within Organizations, in Easterby-Smith, M \& Lyles, M. (eds.) The Blackwell Handbook of Organizational Learning and Knowledge Management, Oxford: Blackwell Publishing 2003.

Tabachnick, B. G. \& Fidell, L. S. (1996). Using Multivariate Statistics ( $3^{\text {rd }}$ eds). New York: Harper Collins.

Tsang E.W.K., Tri D.N. \& Erramilli M.K. (2004). Knowledge Acquisition and Performance of International Joint Ventures in the Transition Economy of Vietnam. Journal of International Marketing, 12(2), p. 82-103.

Uzzi, B. (1997). Social Structure and Competition in Interfirm Networks: The Paradox of embeddedness. Administrative Science Quarterly, 42, p. 35-67.

von Hippel, E. (1994). Sticky Information and the Locus of Problem Solving: Implication for Innovation. Management Science, 40(4), p. 429-439.

Wathne, K., Roos, J. \& von Krogh, G. (1996). Towards a Theory of Knowledge Transfer in a Cooperative Context, in: von Krogh, G. and Roos, J. (Eds.), Managing Knowledge Perspectives on Cooperation and Competition, Sage Publications: London, 51-81.

Wernerfelt, B. (1984). A Resource-Based View of the Firm, Strategic Management Journal, 5(2), p. 171- 80. Yan, A. \& Luo, Y (2001). International Joint Ventures: Theory and Practice, M.E. Sharpe, New York.

Yin, E. \& Bao, Y. (2006). The Acquisition of Tacit Knowledge in China: An Empirical Analysis of the 'Supplier-side Individual Level' and 'Recipient-side' Factors. Management International Review, 46(3), p. $327-348$.

Zand, D.E. (1972). Trust and Managerial Problem Solving. Administrative Science Quarterly, 17, p. $229-239$.

Zander, U. \& Kogut, B. (1995). Knowledge and the Speed of the Transfer and Imitation of Organizational Capabilities: An Empirical Test. Organization Science, 6(1), p. 76-92.

Table 1. Descriptive Statistics and Correlation Matrix.

\begin{tabular}{|l|l|l|l|l|l|}
\hline Variable & Mean & SD & 1 & 2 & 3 \\
\hline RELQLTY & 5.91 & 1.45 & 1.000 & & \\
\hline MT & 7.07 & 1.35 & $0.449^{* *}$ & 1.000 & \\
\hline TCTDEG & 6.29 & 1.31 & $0.481^{* *}$ & $0.720^{* *}$ & 1.000 \\
\hline RELQLTY & 6.47 & 1.34 & 1.000 & & \\
\hline MT & 7.07 & 1.35 & $0.564^{* *}$ & 1.000 & \\
\hline EXPDEG & 6.29 & 1.31 & $0.512^{* *}$ & $0.721^{* *}$ & 1.000 \\
\hline
\end{tabular}

$n=128, * p<0.05, * * p<0.01$

Table 2. Results of group Regression Analysis ${ }^{\mathrm{a}}$

\begin{tabular}{|l|l|l|}
\hline Variable & $\begin{array}{l}\text { Degree of Tacit Knowledge } \\
\text { (Model 1) }\end{array}$ & $\begin{array}{l}\text { Degree of Explicit Knowledge } \\
\text { (Model 2) }\end{array}$ \\
\hline (Constant) & $8.028^{* * *}$ & $8.804 * * *$ \\
\hline Relationship Quality & $0.214^{*}$ & $0.406^{* *}$ \\
\hline Mutual Trust & $0.327^{* *}$ & $0.220^{*}$ \\
\hline$R$-squared & 0.254 & 0.342 \\
\hline Adjusted $R$-squared & 0.242 & 0.331 \\
\hline$F$ & $8.028^{* * *}$ & $8.804 * * *$ \\
\hline
\end{tabular}

${ }^{\text {a }}$ Cell entries are standardised coefficient estimates $(n=128)$

$\dagger p<0.10, * p<0.05, * * p<0.01, * * * p<0.001$ 